\title{
EFEK PENGHAMBATAN EKSTRAK MENGKUDU TERHADAP PERTUMBUHAN PATOGEN DAN PERKEMBANGAN PENYAKIT LAYU BAKTERI TANAMAN PISANG
}

\author{
Efri $^{1}$
}

\begin{abstract}
Inhibitory effect of pace extraction on growth of pathogen and development of bacterial wilt of banana disease. Bacterial wilt of banana (Ralstonia solanacearum) is one of banana diseases that potentially destructs banana plants in some areas. A study on the effect of extract of pace plant against bacterial wilt of banana were carried out in laboratory and experimental farm of Plant Protection Department, College of Agriculture, University of Lampung from May until October 2003. The study consisted of in vitro and intact plant experiments. The treatments for both in vitro and intact plants were (1) steril water (control), (2) extract of pace fruit, (3) extract of pace fruit leaves, (4) extract of pace roots and (5) bactericide (agrymycin sulfate). In vitro study was conducted by using completely randomized design, while intact plant study was conducted by using completely randomized block design. The results showed that extract of fruit, leaf and root of pace suppressed the growth of $R$. solamacearum in vitro. Fruit extract had the highest ability in suppressing the growth of bacterial wilt. However, the application of all kind of extract did not suppress the incident of bacterial wilt of banana plant.
\end{abstract}

Key words: pace, bacterial wilt disease, banana

\section{PENDAHULUAN}

Penyakit layu bakteri merupakan salah satu penyakit yang cukup penting pada tanaman pisang di berbagai daerah bahkan negara penghasil pisang. Penyakit ini disebabkan oleh bakteri yang dikenal dengan nama Ralstonia solanacearum ( $\sin$. Pseudomonas solanacearum) (Mujim dkk., 1999). Di Indonesia, penyakit ini ditemukan pertama kali tahun 1910 di pulau Selayar, Sulawesi Selatan (Semangun,1989) dan setelah itu penyakit ini juga ditemukan tersebar di pulau Jawa. Di Provinsi Lampung, penyakit layu pisang pertama kali dilaporkan pada tahun 1993 (Aeny dkk.,1997) dan sampai saat ini masih merupakan masalah yang serius karena belum berhasil dikendalikan. Penyakit ini menjadi ancaman serius, karena Provinsi Lampung merupakan salah satu pemasok buah pisang baik untuk kebutuhan dalam negeri maupun untuk diekspor.

Seperti diketahui pengendalian tanaman yang disebabkan oleh bakteri pada umumnya sangat sulit dilakukan. Percobaan-percobaan yang dilakukan selama ini belum menunjukan hasil yang memuaskan. Penggunaan antibiotik untuk mengendalikan penyakit tanaman yang disebabkan oleh bakteri masih sangat terbatas dan keberhasilanya seringkali masih dalam skala rumah kaca (Aeny, 1999).

Tanaman mengkudu (Morinda citrifolia) atau pace belakangan ini menjadi sangat populer. Tanaman ini banyak terdapat di Indonesia sebagai tanaman liar atau tanaman pekarangan yang dimanfaatkan sebagai sayuran atau tanaman obat. Khasiatnya yang dapat menyembuhkan berbagai penyakit pada manusia mendorong banyak peneliti untuk melakukan peneltian tentang kandungan tanaman mengkudu serta khasiatnya . Zat-zat yang dikandung dalam tanaman mengkudu adalah sebagai zat antibakteri seperti acubin, alizarin, antraquinon. Zat zat ini terbukti dapat menekan pertumbuhan bakteri Pseudomonas aeruginosa, Proteus morganii, Staphylococus aureus, Bacillus subtilis dan Escherichia coli (Waha, 2000). Dengan khasiat seperti di atas, sangat memungkinkan bahwa mengkudu juga dapat digunakan untuk menghambat pertumbuhan bakteri yang menyebabkan penyakit pada tanaman serta menekan perkembangan penyakit tersebut.

Penelitian ini bertujuan untuk mempelajari pengaruh ekstrak mengkudu terhadap pertumbuhan bakteri Ralstonia (Pseudomonas) solanacearum penyebab penyakit layu pisang dan perkembangan penyakit layu bakteri pada tanaman pisang.

\footnotetext{
${ }^{1}$ Dosen Jurusan Proteksi Tanaman Fakultas Pertanian Universitas Lampung Jl. Sumantri Brodjonegoro, I Bandar Lampung
} 


\section{METODE PENELITIAN}

Percobaan dilakukan di Laborattorium Penyakit Tumbuhan Jurusan Proteksi Tanaman dan kebun percobaan Fakultas Pertanian Universitas Lampung Bandar Lampung. Penelitian dilaksanakan pada bulan Mei sampai Oktober 2003.

\section{Rancangan Percobaan}

Penelitian ini dilakukan dua sub percobaan yaitu percobaan di laboratorium secara in vitro dan dilanjutkan dengan percobaan semi lapang memakai polibag (intact plant).

\section{Percobaan secara in vitro}

Dalam percobaan secara in vitro digunakan rancangan acak lengkap dengan perlakuan terdiri atas air steril sebagai kontrol (T1) ekstrak buah mengkudu (T2) ekstrak daun mengkudu (T3), ekstrak akar mengkudu (T4) dan bakterisida Agrimicyn sulfat (T5) - Semua perlakuan diulang sebanyak lima kali. Data yang diperoleh diolah dengan sidik ragam dan dilanjutkan dengan uji beda nyata terkecil (BNT).

Ektrak daun, akar dan buah mengkudu diperoleh dengan menggunakan juicer/blender. Pengujian kemampuan ekstrak mengkudu dilakukan dengan dua metode yaitu (1) metode bor gabus untuk mengukur zona penghambatan pertumbuhan bakteri $R$ solanacearum dan (2) metode pencampuran untuk mengukur diameter koloni bakteri $R$. solanacearum.

\section{Metode Bor Gabus (Mengukur zone penghambatan)}

Potongan-potongan media agar berbentuk cakram yang dibentuk dari bor gabus ditetesi dengan larutan ekstrak mengkudu sesuai dengan perlakuan . Masing-masing potongan ditetesi dengan $0.5 \mathrm{ml}$ ekstrak dan didiamkan selama 5 menit agar meresap. Kemudian potongan-potongan agar tersebut diletak pada media AGK (agar gula kentang) pada petridish yang telah dicampur dengan suspensi bakteri $R$ solanacearum. Pada masing-masing petridish terdapat tiga potongan agar dan diinkubasi pada suhu kamar selama 24 jam. Pengamatan dilakukan terhadap zona penghambatan yang terbentuk yaitu daerah yang tidak ditumbuhi bakteri disekeliling potongan cakram agar (ditunjukan dengan adanya zona bening) dan diukur diameternya.

2. Metode Pencampuran (mengukur jari-jari koloni bakteri)

Masing-masing ekstrak yang diuji dicampurkan pada media AGK $(25 \mathrm{ml}: 75 \mathrm{ml})$ dan kemudian dituangkan kedalam cawan petri. Setelah media membeku kemudian diinokulasi dengan isolat bakeri $R$. solanacearum. Masing-masing cawan petri diinokulasi dengan tiga lup inokulum yang diletak pada tempat yang berbeda. Dan kemudian di inkubasi selama 24 jam. Pengamatan dilakukan terhadap perkembangan diameter koloni bakteri yang terbentuk.

\section{Percobaan Semi Lapangan (intact plant)}

Percobaan ini menggunakan rancangan acak kelompok dengan tiga ulangan . Seperti halnya percobaan in vitro perlakuan terdiri dari air steril sebagai kontrol (T1), ekstrak buah mengkudu (T2), ekstrtak daun mengkudu (T3), ekstrak akar mengkudu (T4), dan baktresida Agrymicin sulfat (T5)

Masing-masing perlakuan pada setiap perlakuan terdiri dari 4 tanaman. Data yang diperoleh yaitu keterjadian penyakit (disease incidence) diolah dengan sidik ragam dan dilanjutkan dengan uji Beda Nyata Terkecil (BNT).

Perlakuan diaplikasikan pada tanaman yang telah disiapkan di polibag dengan cara menyiramkan ekstrak mengkudu di permukaan tanah sebanyak 250 $\mathrm{ml}$ pertanamam. Inokulasi patogen dilakukan satu minggu setelah aplikasi dengan cara menyuntikan suspensi bakteri (Optical Density, OD $=1$ pada panjang gelombang 600) pada pangkal batang sebanyak $10 \mathrm{ml} /$ tanaman. Pengamatan dan pengambilan data dilakukan sejak gejala layu muncul untuk pertama kali sampai semua tanaman mati pada perlakuan kontrol. Keterjadian penyakit dihitung dengan menggunakan rumus:

$$
\mathrm{P}=\mathrm{n} / \mathrm{N} \times 100 \%
$$

Keterangan:

$$
\begin{aligned}
& \mathrm{P}=\text { keterjadian penyakit } \\
& \mathrm{n}=\text { jumlah tanaman yang mengalami gejala } \\
& \text { layu } \\
& \mathrm{N}=\text { jumlah tanaman yang diamati. }
\end{aligned}
$$




\section{HASIL DAN PEMBAHASAN}

\section{Percobaan secara in vitro}

Hasil pengamatan terhadap zona penghambatan dan pertumbuhan koloni bakteri $R$. solanacearum menunjukan bahwa ekstrak mengkudu (buah, daun dan akar) seperti halnya bakterisida mempunyai pengaruh nyata dalam menahan pertumbuhan bakteri (Tabel 1). Ekstrak buah, ekstrak daun dan ekstrak akar mempunyai pengaruh yang cukup baik bila dibandingkan dengan kontrol (air steril) dan bakterisida dalam pembentukan zona penghambatan. Demikian pula halnya terhadap perkembangan koloni $R$. solanacearum, bahkan ekstrak buah mengkudu mempunyai kemampuan yang sama dengan kemampuan bakterisida.

Ekstrak tanaman mengkudu mempunyai potensi yang cukup baik untuk menghambat perkembangan bakteri $R$. solanaceraum secara in vitro. Dari ketiga bagian tanaman tersebut (buah, daun dan akar), ekstrak buah mempunyai efek yang lebih baik dibandingkan dengan yang lain bahkan efeknya tidak berbeda dengan bakterisida. Ekstrak mengkudu adalah bahan alami yang banyak mengandung senyawa fenol.

Tabel 1. Pengaruh Ekstrak Tanaman Mengkudu dan Bakterisida terhadap Diameter Zona penghambatan dan perkembangan Diameter Koloni Bakteri $R$. sonacearum ( $\mathrm{mm})$

\begin{tabular}{lcr}
\hline Perlakuan & Diameter Zona penghambatan & Diameter Koloni \\
\hline Air Steril /Kontrol (T1) & $0,00 \mathrm{e}$ & $11,62 \mathrm{a}$ \\
Ekstrak buah (T2) & $3.46 \mathrm{~b}$ & $3,16 \mathrm{~d}$ \\
Ekstrak daun (T3) & $2.50 \mathrm{c}$ & $5,95 \mathrm{c}$ \\
Ekstrak akar (T4) & $1,38 \mathrm{~d}$ & $9,43 \mathrm{~b}$ \\
Bakterisida (T5) & $5,28 \mathrm{a}$ & $3,48 \mathrm{~d}$
\end{tabular}

Keterangan: Pemberian notasi huruf setelah pengolahan data yang ditranformasi dengan akar $(x+1)$.

Angka-angka yang diikuti huruf yang sama tidak berbeda nyata pada taraf 0,05 dengan uji BNT.

Tabel 2. Pengaruh ekstrak tanaman mengkudu dan bakterisida terhadap keterjadian penyakit (\%)

\begin{tabular}{|c|c|c|c|c|c|}
\hline Perlakuan & !0 hsi & !4 hsi & $17 \mathrm{hsi}$ & 20 hsi & $23 \mathrm{hsi}$ \\
\hline Kontrol (T1) & $16.66 \mathrm{a}$ & $66,66 \mathrm{a}$ & $83.33 \mathrm{a}$ & 91,86 a & $100,00 \mathrm{a}$ \\
\hline Buah (T2) & 8,33 a & $25,00 \mathrm{a}$ & $66,66 \mathrm{a}$ & $83,33 \mathrm{a}$ & $100,00 \mathrm{a}$ \\
\hline Daun (T3) & $0,00 \mathrm{a}$ & $25.00 \mathrm{a}$ & $50,00 \mathrm{a}$ & $75,00 \mathrm{a}$ & $83,33 \mathrm{a}$ \\
\hline Akar (T4) & $0,00 \mathrm{a}$ & $8,33 \mathrm{a}$ & $50,00 \mathrm{a}$ & $66,66 \mathrm{a}$ & 83,33 a \\
\hline Bakterisida (T5) & $0,00 \mathrm{a}$ & $41,66 \mathrm{a}$ & $66,66 \mathrm{a}$ & 83,33 a & 91,66 a \\
\hline $\mathrm{F}$ & 2,29 & 1,84 & 0,37 & 0,38 & 0,53 \\
\hline $\operatorname{Pr}>\mathrm{F}$ & 0,14 & 0,29 & 0,82 & 0,81 & 0,71 \\
\hline
\end{tabular}

Keterangan: Pemberian notasi huruf setelah pengolahan data yang ditranformasi dengan akar $(x+1)$. Angka-angka yang diikuti huruf yang sama tidak berbeda nyata pada taraf 0.05 dengan uji BNT. hsi : hari setelah inokulasi. 
Senyawa fenol ini diantaranya adalah antrakuinon, acubin dam alizarin. Senyawa fenol dapat bertindak sebagai senyawa antibakteri dengan cara menurunkan tegangan permukaan memberan sel dan berkombinasi dengan protein pada sel bakteri sehinga fungsinya menjadi tidak normal. (Volk dan Wheeler, 1984). Kandungan senyawa fenol pada tanaman mengkudu kemungkinan lebih banyak terdapat pada buah mengkudu, oleh karena itu pengaruhnya terhadap Ralstonia solanacearum lebih baik dibandingkan dengan bagian tanaman yang lain. Berdasarkan hasil penelitian in vitro ini ternyata ekstrak tanaman mengkudu dapat juga bertindak sebagai bakterisida terhadap Ralstonia solanacearum sepertihalnya yang telah dibuktikan terhadap Pseudomonas aeroginosa, Proteus morganii, Staphylococcus aureus, Bacillus subtilis dan Escherichia coli (Waha, 2000).

\section{Percobaan semi lapang (intact plant)}

Gejala layu mulai tampak sejak 10 hari setelah inokulasi suspensi bakteri Ralstonia solanacearum pada tanaman pisang yang ditanam pada polibag. Gejala layu pertama kali muncul pada tanaman yang diperiakukan dengan air steril ( kontrol) dan pada tanaman yang diberi perlakuan ekstrak buah mengkudu. Hasil percobaan ini tidak cukup kuat untuk dinyatakan bahwa perlakuan mempunyai pengaruh yang nyata ( $\mathrm{Pr}>0,1486)$ terhadap persentase tanamam yang mengalami kelayuan (keterjadian penyakit) (Tabel 2). Ekstrak tanaman mengkudu (buah, daun dan akar), bakterisida dan air steril tidak mempunyai pengaruh yang berbeda dalam menekan perkembangan keterjadian penyakit layu bakteri pada tanaman pisang. Namun demikian kalau kita amati perkembangan penyakit mulai 10 hari setelah inokulasi sampai 23 hari setelah inokulasi tampak ada kecenderungan bahwa perlakuan ekstrak tanaman dan bakterisida dapat memperlambat keterjadian penyakit (Gambar 1). Pada Gambar 1 nampak perlakuan ekstrak tanaman terutama ekstrak akar berada dibawa perlakuan air steril (kontrol), Perkembangan keterjadian penyakit pada tanaman yang diberi perlakuan ekstrak tanaman mengkudu jauh lebih lambat dibandingkan dengan perlakuan air steril.

Aplikasi ekstrak mengkudu pada tanaman nampaknya tidak memberi hasil yang konsisten seperti percobaan secara in vitro. Pada akhir percobaan hampir semua tanaman yang diperlakukan mengalami kematian. Hal ini mungkin saja disebabkan karena tanaman mengalami tekanan berat karena akibat perlakuan inokulasi suspensi bakteri secara injeksi.

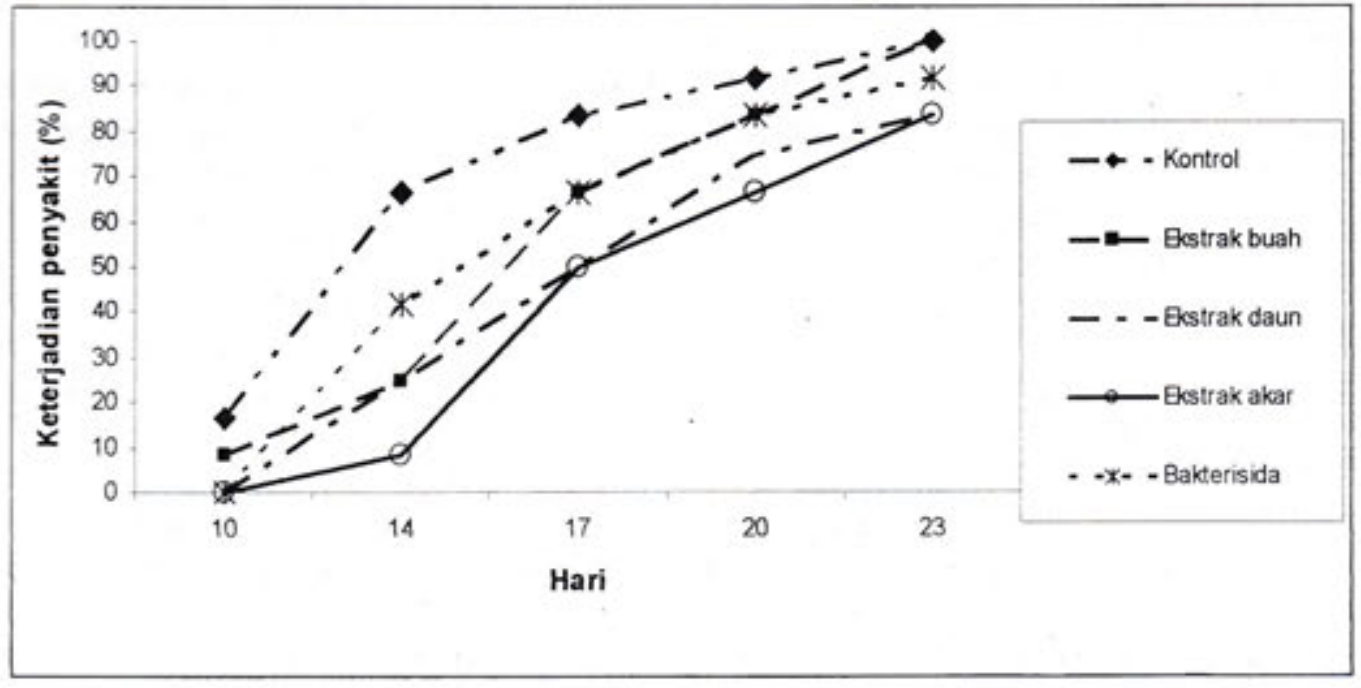

Gambar 1. Perkembangan keterjadian penyakit layu bakteri pada tanaman pisang yang diperlakukan dengan ekstrak mengkudu 


\section{SIMPULAN DAN SARAN} bahwa:

Dari hasil percobaan ini dapat disimpulkan

1. Ekstrak tanaman mengkudu (buah daun dan akar) menekan pertumbuhan bakteri $R$. solanacearum secara in vitro. Ekstrak buah mempunyai kemampuan yang lebih baik dibandingkan dengan bagian tanaman yang lainnya.

2. Aplikasi ekstrak mengkudu pada tanaman tidak memberikan hasil yang nyata untuk menekan keterjadian penyakit layu bakteri pada tanaman pisang.

Perlu dilakukan penelitian lebih lanjut tentang aplikasi ekstrak tanaman mengkudu, terutama bagian buah dengan memperbaik teknik inokulasi bakteri $R$ solanacearum pada tanaman pisang dan memperbesar jumlah sampel.

\section{SANWACANA}

Penulis menyampaikan terimakasih kepada Ir. Titik Nur Aeny, M.Sc., Nova Anggraeni, S.P. dan Ani Maryani yang telah membantu pelaksanaan penelitian ini.

\section{DAFTAR PUSTAKA}

Aeny, T. N., S. Mujim, \& Efri. 1997. Intensitas Penyakit Layu Bakteri (Pseudomonas solanacearum) pada beberapa Kultivar Pisang. Prosiding Kongres Nasional XIV dan Seminar Ilmiah Perhimpunan Fitopatologi Indonesia. Palembang 27-29 Oktober 1997. Vol. $1 \mathrm{hlm}$. 467-469.

Aeny, T. N.. 1999. Pengaruh Bakterisida dan Fungisida terhadap Intensitas Penyakit Layu Bakteri (Pseudomonas solanacearum) pada Pisang. J. Pen. Pengembangan Wilayah Lahan Kering. No. 22/23.

Mujim, S. , T. N. Aeny, C. Ginting, S. Kusumoto, Y. Takikawa, S. Tsuyumu \& T. Tsuge. 1999. Bacterial Wilt of Bananas in Lampung Indonesia. In Proceeding of the International Symposium. October19-20, 1999. Asian Natural Environmental Science Center. The United Nation University. Tokyo 269-272 pp

Semangun, H. 1989. Penyakit-penyakit Tanaman Hortikultura di Indonesia. Gajah Mada University Press, Yogyakarta. $850 \mathrm{hlm}$.

Volk \& Wheller. 1984. Mikrobiologi Dasar. Diterjemahkan oleh Soenartono Adisoemarto. Erlangga, Jakarta. $396 \mathrm{hlm}$.

Waha, 2001. Sehat dengan Mengkudu (Morinda citrifolia). MSF Group. Jakarta. $43 \mathrm{hlm}$. 